\title{
Development of MEDI4736, an anti-programmed cell death ligand 1 (PD-L1) antibody, as monotherapy or in combination with other therapies in the treatment of non-small cell lung cancer (NSCLC)
}

\author{
Julie Brahmer ${ }^{*}$, Ani Balmanoukian², Sarah Goldberg ${ }^{3}$, Sai-Hong Ou ${ }^{4}$, Andrew Blake-Haskins ${ }^{5}$, Joyson Karakunnel ${ }^{5}$, \\ Paul Stockman', Naiyer Rizvi ${ }^{7}$, Scott Antonia ${ }^{8}$
}

From Society for Immunotherapy of Cancer 29th Annual Meeting

National Harbor, MD, USA. 6-9 November 2014

\section{Background}

MEDI4736 is an engineered human IgG1 that blocks PD-L1 binding to PD-1 and allows T-cells to recognize and kill tumor. MEDI4736 has single-agent activity and potential for further increased activity in combination. A comprehensive development programme is underway in NSCLC, as monotherapy and in combination.

\section{Methods}

NSCLC data from 2 multicentre, open-label Phase I studies are reported. NCT01693562 evaluates safety and efficacy of MEDI4736 administered every 2 or 3 weeks. NCT02000947 evaluates safety and efficacy of MEDI4736 in combination with tremelimumab, a human IgG2 antiCTLA-4 mAb, at 4-week intervals.

\section{Results}

NCT01693562: As of May 2014, NSCLC cohort included 155 patients (pts) (median age 65 years [3385], PS 0/1/unknown [25\%/73\%/2\%], median 3 [0-7] prior treatments). Median follow-up: 6 weeks (range 067). Treatment-related adverse events (TRAEs): $29 \%$ (Grade $[\mathrm{Gr}] \geq 3: 3 \%$ ); none led to treatment discontinuation. Most frequent TRAEs: fatigue (7\%), nausea (5\%), and vomiting (5\%). No treatment-related colitis any $\mathrm{Gr}$. No treatment-related Gr 3/4 pneumonitis or dyspnea.

'Sidney Kimmel Comprehensive Cancer Center at John Hopkins University, Baltimore, MD, USA

Full list of author information is available at the end of the article
58 pts had $\geq 12$ weeks follow-up: $16 \%$ had partial response (as early as 6 weeks), duration of response ranged 5-54+ weeks, disease control rate $35 \%$. PD-L1 positivity appears to enrich for response.

NCT02000947: As of April, 2014, 12 pts treated at 4 dose-levels (PS 0-1, median 3 [2-5] prior treatments). No DLTs observed in any cohort during DLT observation period. Most frequent TRAEs: - $\uparrow$ amylase, abdominal pain, arthralgia, colitis, diarrhea, epigastric discomfort, fatigue and nausea. TRAEs $\geq$ Gr 3 noted in 3 pts: Gr 3 - $\uparrow$ AST/ ALT \& Gr 5 myasthenia (MG) ( $\mathrm{n}=1)$, Gr 3 diarrhea/colitis $(n=1)$, Gr 4 - $\uparrow$ amylase $(n=1)$. TRAEs led to discontinuation in two subjects: Gr 5 MG and Gr3 colitis. In 12 response-evaluable pts (Figure 1), tumor shrinkage at 8 weeks: $0 / 3$ pts cohort $1 \mathrm{a} ; 6 / 9$ pts cohorts $2 \mathrm{a}$ and $3 \mathrm{a} / \mathrm{b}$; disease control: 7/12 pts. Dose-escalation ongoing; total of 6 dose-levels, including cohort 5a (MEDI4736/Treme: 15/10 $\mathrm{mg} / \mathrm{kg}$ ), has been cleared since cut-off.

\section{Conclusions}

Current safety profile and encouraging early antitumor activity (monotherapy and combination) support continued development in NSCLC. Additional monotherapy NSCLC studies: Phase II 'ATLANTIC' (NCT02087423), Phase III 'PACIFIC' following chemo-radiotherapy (NCT02125461), Combination: Phase I + gefitinib (NCT02088112), and Phase Ib + AZD9291 (NCT02143466). Monotherapy and combination: Phase III 'ARCTIC' vs standard-of-care. 
doi:10.1186/2051-1426-2-S3-P179

Cite this article as: Brahmer et al.: Development of MEDI4736, an antiprogrammed cell death ligand 1 (PD-L1) antibody, as monotherapy or in combination with other therapies in the treatment of non-small cell lung cancer (NSCLC). Journal for ImmunoTherapy of Cancer 2014 2(Suppl 3):P179.

Submit your next manuscript to BioMed Central and take full advantage of:

- Convenient online submission

- Thorough peer review

- No space constraints or color figure charges

- Immediate publication on acceptance

- Inclusion in PubMed, CAS, Scopus and Google Scholar

- Research which is freely available for redistribution

Submit your manuscript at www.biomedcentral.com/submit 